\title{
A STUDY ON CUSTOMER OPINION AND CUSTOMER ACCEPTANCE ON MUTUAL FUNDS WITH SPECIAL REFERENCE TO RELIGARE SECURITIES LIMITED KUMBAKKONAM
}

\author{
K. Keerthi ${ }^{1}$, A. Arulraj ${ }^{2}$ and K. Bharathipriya ${ }^{3}$ \\ ${ }^{I}$ Department of Management Studies, A.V.C. College of Engineering, India \\ ${ }^{2}$ Department of Economics, Rajah Serfoji Government College, India \\ ${ }^{3}$ Department of Business Administration, Sengamalathayar Educational Trust Women's College, India
}

\begin{abstract}
The concept of 'customer opinion and customer acceptance' is always seen as a widely accepted area of research amongst the academicians. Studies on customer opinion have showed that customer satisfaction is strongly dependent on the perceived experience and prior expectation of the customers. The gap between the level of expectations and the level of experience act as an indicator of the success or the future prospects of a product. A product is expected to satisfy the needs and expectations of the customers. Similarly, mutual funds are expected to fulfill the investment needs of the investors. This paper assessed the retail investors' level of experience and level of expectations from mutual fund investments in terms of the 'customer communication dimension' of the marketing mix. The study was conducted in Kumbakonam with a sample size of 50 respondents. Percentage analysis and cross tab tools are used to identify the customer satisfaction level of mutual funds.
\end{abstract}

\section{Keywords \\ Customer Satisfaction, Customer Expectations, Customer Experience, Mutual Funds, Investment}

\section{INTRODUCTION}

A Mutual fund is a body corporate that pools the savings of a number of investors and invests the same in a variety of different financial instruments, or securities. The income earned through these investments and the capital appreciation realized by the scheme is shared by its unit holders in proportion to the number of units owned by them. Mutual funds can thus be considered as financial intermediaries, in the investment business that collect funds from the public and invest on behalf of the investors. The losses and gains accrue to the investors only. The investment objectives outlined by a Mutual fund in its prospectus are binding on the Mutual fund scheme. The investment objectives specify the class of securities a Mutual fund can invest in, Mutual funds invest in various asset classes like equity, bonds, debentures, commercial paper and government securities.

In reviewing various studies into what drives organizational success, it is clear that there are many ways to succeed. The fad of the day may grab headlines and create bestsellers with receipts for business success. But ongoing and constructive debate continues about the relevance and value of today's fashionable practices when compared to long-established commercial principles and approaches.

What appear to shine through this debate are two fundamental concepts.

- Firstly, that companies which are most successful over the long term are those which incorporate their cultural values at the core of their everyday business operations, i.e. they implement values-based management practices.

- Secondly, it is the basics that matter - comprised of both the business values that underpin a company's culture and the business value proposition offered to customers and stakeholders.

- A more holistic view of business combining these two concepts elevates the importance of the cultural and emotional well-being of a company and its people - the emotional quotient - alongside organizational objectives such as return on investment. The right mix of these should ensure that companies celebrate success. This is enumerated in the brand of the company.

- By being transparent about values and allowing customers and partners to experience these values at every interaction, a company will distinguish itself from its competitors.

\subsection{VALUE BASED MANAGEMENT PRACTICES}

Almost everyone endorse the view that values should underpin all management practices and advocates that corporations must see values as the foundation upon which the edifice of value creation must rest.

Business are living entities that should constantly evolve. Evolving companies as those, which among other things

- Define their purpose in terms that embrace the common good.

- They have corporate values that both reflect the collective values of all employees and align with individual values.

- Their leaders harness the emotions and spirit of every individual toward a common purpose that everyone understands while being authentic in their values and commitment to social responsibility.

- These evolving businesses are a good reflection of organizations with their corporate culture and business practices underpinned by core values.

- Researcher believes that by being transparent about values and allowing customers and partners to experience these values at every interaction, a company will distinguish itself from its competitors.

- Researcher limited experience has been that companies, especially highly successful ones, operate in a constant state of evolution. In fact, the more successful a company is, the more willing it tends to be to re-engineer itself right to the core. It is also willing to use its values-based management practices to evolve and improve its relationships and co- 
dependencies in its customer and partner ecosystem to support achievement of its business goals.

\subsection{VALUE CENTRIC BUSINESS}

An evolved business knows How to balance self-interest with common good. It understands that to generate and retain customer loyally it needs to provide more than functional or economic value through the goods and services it provides. Such a business grows by developing an emotional connection with its customers and its partners. This emotionally derived value is driven by intangibles such as service experiences, trusted relationships and brand reputation.

As much of this value is intangible cultural capital, it is often one of the most under-estimated and under-invested areas by organizations. Yet, considerable evidence suggests there is a strong link between such psychological value and an organization's effectiveness. In built to last successful habits of Visionary focused on developing a strong corporate culture over a period of several decades.

As an example, Microsoft is a company which is the evolutionary process toward a company values and business value model. And with in-depth employee collaboration, Microsoft has developed a comprehensive set of company values to underpin every aspect of what each employee does to deliver business value to customers, partners and the wider community.

Researcher view is that for a company values and business value management approach to be sustainable, it needs to be built on four district pillars.

- Values must be embedded organization wide to provide a platform for common purpose and promote an understanding of a company's strategic mission.

- Values must be at the core of business engagements and be transparent it day-to-day operations.

- Values must be aligned with customer expectations of an organization operating in a trusted relationship.

- Values are company defined, value is customer-defined.

Such values-based practices are important because as Peter Ducker, the patriarch of management theory observes: "What the business thinks it produces is not of first importance. What the customer thinks he is buying, what he considers value, is decisive."

The view of Shawney, that true customer-centricity demands that you believe and act on the basis of customer value, is sound. As he contends, you cannot offer value to customers without first changing you organization's values, even if it means getting back to the basics. Ultimately, what companies believe in determines how they think and act. Their actions and behaviors in turn manifest themselves in their offerings [10].

Researcher concur with Sawhneys' belief that firms which adopt the value mindset think differently about the customers they focus on, the value proposition they create for their customers, the growth strategy they employ, the way they organize their marketing and sales organization, and the way they measure and reward success [11].

"Success metrics", "Product revenues" and "Product Profitability". These declare success at product sale, Customer satisfaction, profitability and growth. Declare success when customers experience is success. Monitoring and tracking periodic surveys of customer satisfaction with products. Ongoing tracking and continuous improvement of the total customer experience. Hence this project was undertaken to find the "Customer opinion and acceptance of Mutual Funds" [13].

\subsection{PRODUCT PROFILE ASSET MANAGEMENT COMPANY}

An Asset Management Company (AMC) is a highly regulated organization that pools money from investors and invests the same in a portfolio. They charge a small management fee, which is normally $1.5 \%$ of the total funds managed.

\subsubsection{Net Asset Value:}

NAV or Net Asset Value of the fund is the cumulative market value of the assets of the fund net of its liabilities. NAV per unit is simply the net value of assets divided by the number of units outstanding, Buying and selling into funds is done on the basis of NAV-related prices, NAV is calculated as follows:

$\mathrm{NAV}=($ Market value of the funds' investments + Receivables + Accrued Income- Liabilities - Accrued Expenses) / Number of

Outstanding Units

\subsubsection{NAV Declaration:}

The NAV of a scheme has to be declared at least once a week. However many Mutual Fund declare NAV for their schemes on a daily basis. As per SEBI Regulations, the NAV of a scheme shall be calculated and published at least in two daily newspapers at intervals not exceeding one week. However, NAV of a close ended scheme targeted to a specific segment or any monthly income scheme (which is not mandatory required to be listed on a stock exchange) may be published at monthly or quarterly intervals.

\subsection{BENEFITS OF INVESTING IN MUTUAL FUNDS}

- Qualified and experienced professionals manage Mutual funds. Generally, investors, by themselves, may have reasonable capability, but to assess a financial instrument a professional analytical approach is required in addition to access to research and information and time and methodology to make sound investment decisions and keep monitoring them.

- Since Mutual funds make investments in a number of stocks, the resultant diversification reduces risk. They provide the small investors with an opportunity to invest in a larger basket of securities.

- The investor is spared the time and effort of tracking investments, collecting income, etc. from various issuers, etc.

- It is possible to invest in small amounts as and when the investor has surplus funds to invest.

- Mutual funds are registered with SEBI. SEBI monitors the activities of Mutual funds.

- In case of open-ended funds, the investment is very liquid as it can be redeemed at any time with the fund unlike direct investment in stocks/bonds. 


\subsection{RISKS INVOLVED IN INVESTING IN MUTUAL FUND}

Mutual Funds do not provide assured returns. Their returns are linked to their performance. They invest in shares, debentures and deposits. All these investments involve an element of risk. The unit value may vary depending upon the performance of the company and companies may default in payment of interest/principal on their debentures/bonds/deposits. Besides this, the government may come up with new regulation, which may affect a particular industry or class of industries. All these factors influence the performance of Mutual funds.

\subsection{ISSUERS OF MUTUAL FUNDS IN INDIA}

Unit Trust of India was the first mutual fund, which began operations in 1964. Other issuers of Mutual funds are public sector banks like SBI, Canara Bank, Bank of India, Institutions like IDBI, ICICI, GIC, LIC, foreign institutions like Alliance, Morgan Stanley, Templeton and private financial companies like Kothari Pioneer, DSP Merrill Lynch, Sundaram, Kotak Mahindra, Cholamandalam etc [1] [3]-[5].

\subsection{FACTORS THAT INFLUENCE PERFORMANCE OF MUTUAL FUNDS}

THE

The performances of mutual funds are influenced by the performance of the stock market as well as the economy as a whole. Equity funds are influenced to a large extent by the stock market. The stock market in turn is influenced by the performance of the companies as well as the economy as a whole. The performance of the sector funds depends to a large extent on the companies within that sector. Bond-funds are influenced by interest rates and credit quality. As interest rates rise, bond prices fall, and vice versa, similarly, bond funds with higher credit ratings are less influenced by changes in the economy.

\subsection{SELECTION OF A PARTICULAR SCHEME}

Choice of any scheme would depend to a large extent on the investor preferences. For the investor willing to undertakes risks, equity funds would be the most suitable as they offer the maximum returns. Debt funds are suited for those investors who prefer regular income and safety. Gilt funds are best suited for the medium to long-term investors who are averse to risk, balanced funds are ideal for medium-to long-term investors willing to take moderate risks. Liquid funds are ideal for corporate, institutional investors and business houses that invest their funds for very short periods. Tax saving funds are ideal for those investors who want to avail tax benefits. An important aspect while selecting a particular scheme is the duration of the investment. Depending on your time horizon you can select a particular scheme. Besides all this, factors like promoter's image, objective of the fund and returns given by the funds on different schemes should also be taken into account while selecting a particular scheme.

\subsection{RIGHTS THAT ARE AVAILABLE TO MUTUAL FUND HOLDER}

As per SEBI Regulations on mutual, an investor is entitled to
- Receive unit certificates or statements of accounts confirming your title within 6 weeks from the date your request for a unit certificate is received by the mutual fund.

- Receive information about the investment policies, investment objectives, financial position and general affairs of the scheme.

- Receive dividend within 42 days of their declaration and receive the redemption or repurchase proceeds within 10 days from the date of redemption or repurchase.

- The trustees shall be bound to make such disclosures to the unit holders as are essential in order to keep them informed about any information which may have an adverse bearing on their investments.

- $75 \%$ of the unit holders with the prior approval of SEBI can terminate the AMC of the fund.

- $75 \%$ of the unit holders can pass a resolution to wind-up the scheme.

- An investor can send complaints to SEBI, who will take up the matter with the concerned mutual funds and follow up with them till they are resolved.

\subsection{PERFORMANCE OF MUTUAL FUNDS DE MYSTIFIED}

The performance of mutual funds is calculated on the basis of absolute increase or decrease in its Net Asset Value (NAV). However a fund's performance should be evaluated on the basis of a comparison with the relevant indices and alternative instruments. The NAV varies from fund to fund. Therefore this argument is not entirely true. However, some funds have performed poorly with their NAV quoting well their original IPO price.

\section{REVIEW OF LITERATURE}

Bihari et al. [2] have spotted the most vital problem is of ignorance. Investors should be made aware of the benefits. Nobody will invest until and unless he is fully convinced. Investors should be made to realize that ignorance is no longer bliss and what they are losing by not investing. Mutual fund offers a lot of benefit which no other single option could offer but most of the people are not even aware of what actually a mutual fund is? They only see it as just another investment option. So the advisors should try to change their mindset. The advisors should target for more and more young investors. Young investors as well as persons at the height of their career would like to go for advisors due to lack of expertise and time. Mutual Fund Company needs to give the training to the individual financial advisors about the fund or schemes and its objectives, because they are the main source of influence to investors.

Carole [6] have observed that while buying funds, it is important to understand investment risk. There are 3 basic types of risk: market risk, credit risk, and inflation risk. The less risk taken, the smaller the potential return. How much risk one should take depends largely on how long the money will be invested. The more time one has, the more risk one can afford. Asset allocation refers to dividing money among a variety of investments. When one sector of the market performs poorly, 
another sector may offset the losses. To diversify a fund portfolio, Holdings should be split among domestic and international stocks and bonds and money market funds. Funds are a convenient way to employ an asset allocation strategy.

Nihar and Satya [7] one of the successful recent financial innovations is the mutual funds. Mutual fund industry has evolved in to a market that caters to every investment objective of the investor, as the products offered provide a range of benefits like, retirement savings, investment products for tax, deferred individual retirement plans, capital appreciation, regular savings and return. The most important evaluation criterion an individual investor considers for investing in a fund is its past performance. The individual investors need to understand that past performance of a fund is not be read independently but jointly with investment style, expense ratios, minimum investment, fund manager and his personal investment, governance structure etc.

Kaur et al. [8] have observed Mutual funds in India have not been as favorable investment alternatives as in developed countries, as assets under management of mutual funds to gross domestic product in India have been $7-8 \%$ compared to $37 \%$ globally. Further, investor base of mutual funds has been narrow, as retail investors constitute $98 \%$ of folios but contributed only 58\% of investments in September 2014. To broaden the investor base for mutual funds in India, it remains imperative to understand the determinants of investment behavior of investors towards mutual funds.

Majed [9] have analyzed that Mutual fund investment strategies, unlike hedge fund strategies, are far less flexible. Hedge funds tend to generally perform well in up as well as down markets. Hedge funds sell short, leverage, use derivatives, control redemptions, and tie compensation to performance. Hedge funds use these tools for exploiting arbitrage opportunities created by indexing, herding of performance, herding of security selection, and rigid legal and institutional structures. Hedge fund managers are exposed to idiosyncratic risk.

Vasudevan and Nishanth [12] has analyzed that gold schemes with the facility to make periodic purchases, floated by Reliance Mutual fund, Kotak Mutual fund and SBI Mutual fund, have seen sizeable inflows, prompting other asset management companies to plan similar product launches. "ETFs were not fully exploiting the possible investor demand for gold because of the lack of awareness, but with the fund-of-fund structure, there is scope for wider investor participation," said Lakshmi Iyer, head-fixed income and products, Kotak Mahindra Asset Management.

\section{RESEARCH METHODOLOGY}

\subsection{SCOPE OF THE STUDY}

- The study was conducted in Kumbakonam.

- The study was about all the Asset Management Companies of Mutual fund in India.

- The study was about customer opinion and acceptance in Mutual funds.

- The sample size is 50 respondents.
- The study can be used for further decision-making and marketing strategy planning of the company.

- The study was useful in assessing the general awareness to the respondents about Mutual Funds.

\subsection{OBJECTIVES OF THE STUDY}

\subsubsection{Primary Objective:}

To study on "Customer opinion and Customer Acceptance with special reference to Mutual Funds in Religare Securities Ltd.".

\subsubsection{Secondary Objective:}

- To know whether the customer had planned their investments and the priority of investments.

- To find out the service provided and level of importance in investments.

- To know the respondents opinion about investing in mutual funds.

- To find out the importance asset management companies.

\subsection{RESEARCH DESIGN}

- The Research design adopted is exploratory research design.

- The Research is qualitative research since the project deals with the quality aspects, of customers. The customer acceptance market size, market growth and market development are explored and information's are obtained.

\subsection{SAMPLING TECHNIQUES}

The sampling techniques used in this study was Convenient Random sampling. The samples size was taken from 50 respondents. The information required for this study was directly collected from the respondents by using questionnaire method as primary source to collect the data.

\subsection{TOOLS ADOPTED}

- Simple percentage analysis

- One-way ANOVA

- Chi-square

\subsection{LIMITATIONS OF THE STUDY}

- The study is restricted to Kumbakonam only.

- Some of the customer's interview was either reluctant or negative in their approach. Most of them were found either busy or pre-occupied.

- The findings and the recommendations given by the study hold good for short period only.

- The sample size is 50 respondents only. 


\section{ANALYSIS AND DISCUSSION}

\subsection{PERCENTAGE ANALYSIS}

Table.1. Socio Economic Profile of Customers

\begin{tabular}{|c|c|c|c|}
\hline \multicolumn{2}{|c|}{ Particulars } & $\begin{array}{c}\text { No. of } \\
\text { respondents }\end{array}$ & Percentage \\
\hline \multirow{5}{*}{ Age } & Below 25 & 1 & 2 \\
\hline & 25 to 35 & 17 & 34 \\
\hline & 35 to 45 & 22 & 44 \\
\hline & Above 45 & 10 & 20 \\
\hline & Total & 50 & 100 \\
\hline \multirow{3}{*}{ Gender } & Male & 37 & 74 \\
\hline & Female & 13 & 26 \\
\hline & Total & 50 & 100 \\
\hline \multirow{6}{*}{ Occupation } & Service & 15 & 30 \\
\hline & Business & 9 & 18 \\
\hline & Professional & 16 & 32 \\
\hline & Retired & 9 & 18 \\
\hline & Housewife & 1 & 2 \\
\hline & Total & 50 & 100 \\
\hline \multirow{5}{*}{ Income } & Below 1.5 lakhs & 20 & 40 \\
\hline & 1.5 to 5 lakhs & 14 & 28 \\
\hline & 5 to 10 lakhs & 12 & 24 \\
\hline & Above10 lakhs & 4 & 8 \\
\hline & Total & 50 & 100 \\
\hline
\end{tabular}

\subsubsection{Age:}

The Table. 1 shows that the respondents age. $44 \%$ of the respondents are belongs to the age group of 35 to 45 years. $34 \%$ of respondents are belongs to the age group of 25 to 35 years. $20 \%$ of respondents are belongs to the age group of above 45 years. $2 \%$ of the respondents are belongs to the age group below 25 years. Therefore majority of the respondents are between 35 to 45 years.

\subsubsection{Gender:}

$74 \%$ respondents are male and $26 \%$ respondents are female. Therefore the majority of the respondents are male.

\subsubsection{Occupation:}

$32 \%$ of the respondents are professionals, $30 \%$ respondents are in service, $18 \%$ of the respondents are in business, $18 \%$ of the respondents are retired, and $2 \%$ of the respondents are housewife. Therefore the majority of the respondents are professional.

\subsubsection{Income Level:}

$40 \%$ of the respondents income is below 1.5 lakhs, $28 \%$ of the respondents income lies between 1.5 to 5 lakhs, $24 \%$ of the respondents income lies between 5 to 10 lakhs, $8 \%$ of the respondents income is above 10 lakhs. Therefore majority of the respondents income level is below 1.5 lakhs.
Table.2. Income of respondents and returns in investment

\section{Crosstab}

Count

\begin{tabular}{|c|c|c|c|c|c|c|}
\hline \multirow[b]{2}{*}{ Income } & \multicolumn{5}{|c|}{ Return } & \multirow[b]{2}{*}{ Total } \\
\hline & $\begin{array}{l}\text { Strongly } \\
\text { disagree }\end{array}$ & Disagree & Neutral & Agree & $\begin{array}{l}\text { Strongly } \\
\text { Disagree }\end{array}$ & \\
\hline $\begin{array}{c}<1.5 \\
\text { Lakhs }\end{array}$ & 1 & 6 & 9 & 3 & 1 & 20 \\
\hline $\begin{array}{l}1.5-5 \\
\text { Lakhs }\end{array}$ & 1 & 3 & 1 & 7 & 2 & 14 \\
\hline $\begin{array}{l}5-10 \\
\text { Lakhs }\end{array}$ & 2 & 1 & 2 & 4 & 3 & 12 \\
\hline $\begin{array}{c}>10 \\
\text { Lakhs }\end{array}$ & 1 & 0 & 1 & 2 & 0 & 4 \\
\hline Total & 5 & 10 & 13 & 16 & 6 & 50 \\
\hline
\end{tabular}

Chi-Square Tests

\begin{tabular}{|c|r|c|c|}
\hline & \multicolumn{1}{|c|}{ Value } & df & $\begin{array}{c}\text { Asymp. Sig. } \\
\text { (2-sided) }\end{array}$ \\
\hline Pearson Chi-Square & $16.457^{\mathrm{a}}$ & 12 & .171 \\
\hline LikeliHood Ratio & 17.942 & 12 & .117 \\
\hline $\begin{array}{c}\text { Linear-by-Linear } \\
\text { Association }\end{array}$ & 0.951 & 1 & .330 \\
\hline N of Valid Cases & 50 & & \\
\hline
\end{tabular}

${ }^{\mathrm{a}} 18$ cells $(90.0 \%)$ have expected count less than 5 . The minimum expected count is 0.40 .

\section{Hypothesis:}

- H0: There is no significant difference between the income of the respondents and return in investment

- H1: There is a significant difference between the income of the respondents and return in investment.

\section{Interpretation:}

- The Table. 2 is inferred that the calculated value is 0.171 . The sig value is greater than 0.05 . So H0 is accepted. Hence, concluded that there is no significant difference between the income of the respondents and the return in investment.

Table.3. Income of respondents and lower risk in investment

\section{Crosstab}

Count

\begin{tabular}{|c|c|c|c|c|c|c|}
\hline \multirow{2}{*}{ Income } & \multicolumn{5}{|c|}{ Lower Risk } & \multirow{2}{*}{ Total } \\
\cline { 2 - 6 } & $\begin{array}{c}\text { Strongly } \\
\text { disagree }\end{array}$ & Disagree & Neutral & Agree & $\begin{array}{c}\text { Strongly } \\
\text { Disagree }\end{array}$ & \\
\hline $\begin{array}{c}<1.5 \\
\text { Lakhs }\end{array}$ & 2 & 6 & 6 & 4 & 2 & 20 \\
\hline $\begin{array}{c}1.5-5 \\
\text { Lakhs }\end{array}$ & 3 & 3 & 5 & 2 & 1 & 14 \\
\hline $\begin{array}{c}5-10 \\
\text { Lakhs }\end{array}$ & 0 & 3 & 8 & 0 & 1 & 12 \\
\hline $\begin{array}{c}>10 \\
\text { Lakhs }\end{array}$ & 2 & 0 & 1 & 0 & 1 & 4 \\
\hline Total & 7 & 12 & 20 & 6 & 5 & 50 \\
\hline
\end{tabular}


Chi-Square Tests

\begin{tabular}{|c|r|c|c|}
\hline & Value & df & $\begin{array}{c}\text { Asymp. Sig. } \\
\text { (2-sided) }\end{array}$ \\
\hline Pearson Chi-Square & $14.485^{\mathrm{a}}$ & 12 & .121 \\
\hline LikeliHood Ratio & 16.769 & 12 & .158 \\
\hline $\begin{array}{c}\text { Linear-by-Linear } \\
\text { Association }\end{array}$ & 0.144 & 1 & .705 \\
\hline N of Valid Cases & 50 & & \\
\hline
\end{tabular}

${ }^{\mathrm{a}} 18$ cells $(90.0 \%)$ have expected count less than 5 . The minimum expected count is 0.40 .

\section{Hypothesis:}

- H0: There is no significant difference between the Income of the respondents and lower risk in investment

- H1: There is a significant difference between the Income of the respondents and lower risk in investment.

\section{Interpretation:}

- The Table. 3 is inferred that the calculated value is 0.271 . The sig value is greater than 0.05 . So H0 is accepted. Hence concluded that there is no significant difference between the income of the respondents and the lower risk in investment.

Table.4. Income of the respondents and the liquidity in investment

\section{Crosstab}

\section{Count}

\begin{tabular}{|c|c|c|c|c|c|c|}
\hline \multirow[b]{2}{*}{ Income } & \multicolumn{5}{|c|}{ Liquidity } & \multirow[b]{2}{*}{ Total } \\
\hline & $\begin{array}{l}\text { Strongly } \\
\text { disagree }\end{array}$ & Disagree & Neutral & Agree & $\begin{array}{l}\text { Strongly } \\
\text { Disagree }\end{array}$ & \\
\hline $\begin{array}{c}<1.5 \\
\text { Lakhs }\end{array}$ & 4 & 3 & 6 & 6 & 1 & 20 \\
\hline $\begin{array}{l}1.5-5 \\
\text { Lakhs }\end{array}$ & 1 & 3 & 6 & 1 & 3 & 14 \\
\hline $\begin{array}{l}5-10 \\
\text { Lakhs }\end{array}$ & 3 & 3 & 1 & 3 & 2 & 12 \\
\hline $\begin{array}{c}>10 \\
\text { Lakhs }\end{array}$ & 0 & 0 & 1 & 3 & 0 & 4 \\
\hline Total & 8 & 9 & 14 & 13 & 6 & 50 \\
\hline
\end{tabular}

\section{Chi-Square Tests}

\begin{tabular}{|c|r|c|c|}
\hline & Value & df & $\begin{array}{c}\text { Asymp. Sig. } \\
\text { (2-sided) }\end{array}$ \\
\hline Pearson Chi-Square & $14.463^{\mathrm{a}}$ & 12 & .271 \\
\hline LikeliHood Ratio & 16.355 & 12 & .176 \\
\hline $\begin{array}{c}\text { Linear-by-Linear } \\
\text { Association }\end{array}$ & 0.641 & 1 & .423 \\
\hline N of Valid Cases & 50 & & \\
\hline
\end{tabular}

${ }^{\mathrm{a}} 18$ cells $(90.0 \%)$ have expected count less than 5 . The minimum expected count is 0.48 .

\section{Hypothesis:}

- H0: There is no significant difference between the Income of the respondents and liquidity in investment

- H1: There is a significant difference between the Income of the respondents and liquidity in investment.

\section{Interpretation:}

- The Table. 4 is inferred that the calculated value is 0.272 . The sig value is greater than 0.05 . So $\mathrm{H} 0$ is accepted. Hence concluded that there is no significant difference between the income of the respondents and the liquidity in investment.

Table.5. Income of the respondents and the Convenience in investment

\section{Crosstab}

Count

\begin{tabular}{|c|c|c|c|c|c|c|}
\hline \multirow{2}{*}{ Income } & \multicolumn{5}{|c|}{ Convenience } & \multirow{2}{*}{ Total } \\
\cline { 2 - 6 } & $\begin{array}{c}\text { Strongly } \\
\text { disagree }\end{array}$ & Disagree & Neutral & Agree & $\begin{array}{c}\text { Strongly } \\
\text { Disagree }\end{array}$ & \\
\hline $\begin{array}{c}<1.5 \\
\text { Lakhs }\end{array}$ & 3 & 4 & 4 & 5 & 4 & 20 \\
\hline $\begin{array}{c}1.5-5 \\
\text { Lakhs }\end{array}$ & 3 & 4 & 2 & 4 & 1 & 14 \\
\hline $\begin{array}{c}5-10 \\
\text { Lakhs }\end{array}$ & 0 & 4 & 3 & 3 & 2 & 12 \\
\hline $\begin{array}{c}>10 \\
\text { Lakhs }\end{array}$ & 1 & 0 & 1 & 0 & 2 & 4 \\
\hline Total & 7 & 12 & 10 & 12 & & 50 \\
\hline
\end{tabular}

Chi-Square Tests

\begin{tabular}{|c|r|c|c|}
\hline & Value & df & $\begin{array}{c}\text { Asymp. Sig. } \\
\text { (2-sided) }\end{array}$ \\
\hline Pearson Chi-Square & $9.015^{\mathrm{a}}$ & 12 & .702 \\
\hline LikeliHood Ratio & 11.952 & 12 & .450 \\
\hline $\begin{array}{c}\text { Linear-by-Linear } \\
\text { Association }\end{array}$ & 0.186 & 1 & .666 \\
\hline N of Valid Cases & 50 & & \\
\hline
\end{tabular}

a20 cells $(90.0 \%)$ have expected count less than 5 . The minimum expected count is 0.48 .

\section{Hypothesis:}

- H0: There is no significant difference between the Income of the respondents and convenience in investment

- H1: There is a significant difference between the Income of the respondents and convenience in investment.

\section{Interpretation:}

- The Table.5 is inferred that the calculated value is 0.702 . This value greater than 0.05. So H0 is accepted. Hence concluded that there is no significant difference between the income of the respondents and the convenience in investment. 
Table.6. Income of the respondents and timely service

Crosstab

\section{Count}

\begin{tabular}{|c|c|c|c|c|c|c|}
\hline \multirow{2}{*}{ Income } & \multicolumn{5}{|c|}{ Timely Service } & \multirow{2}{*}{ Total } \\
\cline { 2 - 6 } & $\begin{array}{c}\text { Strongly } \\
\text { disagree }\end{array}$ & Disagree & Neutral & Agree & $\begin{array}{c}\text { Strongly } \\
\text { Disagree }\end{array}$ & Total \\
\hline $\begin{array}{c}<.5 \\
\text { Lakhs }\end{array}$ & 3 & 10 & 5 & 1 & 1 & 20 \\
\hline $\begin{array}{c}1.5-5 \\
\text { Lakhs }\end{array}$ & 1 & 4 & 5 & 2 & 2 & 14 \\
\hline $\begin{array}{c}5-10 \\
\text { Lakhs }\end{array}$ & 1 & 5 & 3 & 2 & 1 & 12 \\
\hline $\begin{array}{c}>10 \\
\text { Lakhs }\end{array}$ & 1 & 0 & 0 & 2 & 1 & 4 \\
\hline Total & 6 & 19 & 13 & 7 & 5 & 50 \\
\hline
\end{tabular}

Chi-Square Tests

\begin{tabular}{|c|r|c|c|}
\hline & \multicolumn{1}{|c|}{ Value } & df & $\begin{array}{c}\text { Asymp. Sig. } \\
\text { (2-sided) }\end{array}$ \\
\hline Pearson Chi-Square & $11.944^{\mathrm{a}}$ & 12 & .450 \\
\hline LikeliHood Ratio & 13.035 & 12 & .367 \\
\hline $\begin{array}{c}\text { Linear-by-Linear } \\
\text { Association }\end{array}$ & 3.028 & 1 & .082 \\
\hline N of Valid Cases & 50 & & \\
\hline
\end{tabular}

${ }^{\mathrm{a}} 17$ cells $(85.0 \%)$ have expected count less than 5 . The minimum expected count is 0.48 .

\section{Hypothesis:}

- H0: There is no significant difference between the Income of the respondents and timely service

- H1: There is a significant difference between the Income of the respondents and timely service

\section{Interpretation:}

- The Table.6 is inferred that the calculated value is 0.450 . The sig value is greater than 0.05 . So HO is accepted. Hence concluded that there is no significant difference between the income of the respondents and the timely service

Table.7. Income of the respondents and the speedy transaction

\section{Crosstab}

\section{Count}

\begin{tabular}{|c|c|c|c|c|c|c|}
\hline \multirow[b]{2}{*}{ Income } & \multicolumn{5}{|c|}{ Speedy Transaction } & \multirow[b]{2}{*}{ Total } \\
\hline & $\begin{array}{l}\text { Strongly } \\
\text { disagree }\end{array}$ & Disagree & Neutral & Agree & $\begin{array}{l}\text { Strongly } \\
\text { Disagree }\end{array}$ & \\
\hline $\begin{array}{c}<1.5 \\
\text { Lakhs }\end{array}$ & 3 & 7 & 9 & 1 & 0 & 20 \\
\hline $\begin{array}{l}1.5-5 \\
\text { Lakhs }\end{array}$ & 1 & 3 & 7 & 3 & 0 & 14 \\
\hline $\begin{array}{l}5-10 \\
\text { Lakhs }\end{array}$ & 2 & 3 & 3 & 3 & 1 & 12 \\
\hline $\begin{array}{c}>10 \\
\text { Lakhs }\end{array}$ & 1 & 1 & 1 & 0 & 1 & 4 \\
\hline Total & 7 & 14 & 10 & 7 & 2 & 50 \\
\hline
\end{tabular}

Chi-Square Tests

\begin{tabular}{|c|r|c|c|}
\hline & Value & df & $\begin{array}{c}\text { Asymp. Sig. } \\
\text { (2-sided) }\end{array}$ \\
\hline Pearson Chi-Square & $12.523^{\mathrm{a}}$ & 12 & .405 \\
\hline LikeliHood Ratio & 12.128 & 12 & .435 \\
\hline $\begin{array}{c}\text { Linear-by-Linear } \\
\text { Association }\end{array}$ & 1.276 & 1 & .259 \\
\hline N of Valid Cases & 50 & & \\
\hline
\end{tabular}

${ }^{\mathrm{a}} 17$ cells $(85.0 \%)$ have expected count less than 5 . The minimum expected count is 0.16 .

\section{Hypothesis:}

- H0: There is no significant difference between the Income of the respondents and speedy transactions

- H1: There is a significant difference between the Income of the respondents and speedy transaction

\section{Interpretation:}

- The Table.7 is inferred that the calculated value is 0.405 . The sig value is greater than 0.05 . So $\mathrm{H} 0$ is accepted. Hence concluded that there is no significant difference between the income of the respondents and the speedy transaction.

Table.8. Income of the respondents and the Good communication

\section{Crosstab}

Count

\begin{tabular}{|c|c|c|c|c|c|c|}
\hline \multirow{2}{*}{ Income } & \multicolumn{5}{|c|}{ Good Communication } & \multirow{2}{*}{ Total } \\
\cline { 2 - 6 } & $\begin{array}{c}\text { Strongly } \\
\text { disagree }\end{array}$ & Disagree & Neutral & Agree & $\begin{array}{c}\text { Strongly } \\
\text { Disagree }\end{array}$ & \\
\hline $\begin{array}{c}\text { L } 1.5 \\
\text { Lakhs }\end{array}$ & 4 & 5 & 6 & 4 & 1 & 20 \\
\hline $\begin{array}{c}1.5-5 \\
\text { Lakhs }\end{array}$ & 0 & 5 & 3 & 4 & 2 & 14 \\
\hline $\begin{array}{c}5-10 \\
\text { Lakhs }\end{array}$ & 0 & 4 & 6 & 0 & 2 & 12 \\
\hline $\begin{array}{c}>10 \\
\text { Lakhs }\end{array}$ & 0 & 2 & 0 & 2 & 0 & 4 \\
\hline Total & 4 & 16 & 15 & 10 & 5 & 50 \\
\hline
\end{tabular}

Chi-Square Tests

\begin{tabular}{|c|r|c|c|}
\hline & Value & df & $\begin{array}{c}\text { Asymp. Sig. } \\
\text { (2-sided) }\end{array}$ \\
\hline Pearson Chi-Square & $16.326^{\mathrm{a}}$ & 12 & .177 \\
\hline LikeliHood Ratio & 20.785 & 12 & .054 \\
\hline $\begin{array}{c}\text { Linear-by-Linear } \\
\text { Association }\end{array}$ & .811 & 1 & .368 \\
\hline N of Valid Cases & 50 & & \\
\hline
\end{tabular}

a 18 cells $(90.0 \%)$ have expected count less than 5 . The minimum expected count is 0.32 .

\section{Hypothesis:}

- H0: There is no significant difference between the Income of the respondents and good communication 
- H1: There is a significant difference between the Income of the respondents and good communication

\section{Interpretation:}

- The Table. 8 is inferred that the calculated value is 0.177 . The sig value is greater than 0.05 . So H0 is accepted. Hence concluded that there is no significant difference between the income of the respondents and the good communication.

Table.9. Income of the respondents and the Home delivery

\section{Crosstab}

\section{Count}

\begin{tabular}{|c|c|c|c|c|c|c|}
\hline \multirow{2}{*}{ Income } & \multicolumn{5}{|c|}{ Home Delivery } & \multirow{2}{*}{ Total } \\
\cline { 2 - 6 } & $\begin{array}{c}\text { Strongly } \\
\text { disagree }\end{array}$ & Disagree & Neutral & Agree & $\begin{array}{c}\text { Strongly } \\
\text { Disagree }\end{array}$ & \\
\hline $\begin{array}{c}<1.5 \\
\text { Lakhs }\end{array}$ & 1 & 4 & 9 & 6 & 0 & 20 \\
\hline $\begin{array}{c}1.5-5 \\
\text { Lakhs }\end{array}$ & 1 & 3 & 7 & 2 & 1 & 14 \\
\hline $\begin{array}{c}5-10 \\
\text { Lakhs }\end{array}$ & 3 & 3 & 2 & 4 & 0 & 12 \\
\hline $\begin{array}{c}>10 \\
\text { Lakhs }\end{array}$ & 2 & 0 & 1 & 0 & 1 & 4 \\
\hline Total & 7 & 10 & 19 & 12 & 2 & 50 \\
\hline
\end{tabular}

Chi-Square Tests

\begin{tabular}{|c|r|c|c|}
\hline & \multicolumn{1}{|c|}{ Value } & df & $\begin{array}{c}\text { Asymp. Sig. } \\
\text { (2-sided) }\end{array}$ \\
\hline Pearson Chi-Square & $18.017^{\mathrm{a}}$ & 12 & .115 \\
\hline LikeliHood Ratio & 17.725 & 12 & .124 \\
\hline $\begin{array}{c}\text { Linear-by-Linear } \\
\text { Association }\end{array}$ & 1.458 & 1 & .227 \\
\hline N of Valid Cases & 50 & & \\
\hline
\end{tabular}

a 18 cells $(90.0 \%)$ have expected count less than 5 . The minimum expected count is 0.16 .

\section{Hypothesis:}

- H0: There is no significant difference between the Income of the respondents and home delivery

- H1: There is a significant difference between the Income of the respondents and home delivery

\section{Interpretation:}

- The Table.9 is inferred that the calculated value is 0.115 . The sig value is greater than 0.05 . So H0 is accepted. Hence concluded that there is no significant difference between the income of the respondents and the home delivery.

Table.10. Income of the respondents and the cost effective

\section{Crosstab}

\section{Count}

\begin{tabular}{|c|c|c|c|c|c|c|}
\hline \multirow{2}{*}{ Income } & \multicolumn{5}{|c|}{ Cost Effective } & \multirow{2}{*}{ Total } \\
\cline { 2 - 6 } & $\begin{array}{c}\text { Strongly } \\
\text { disagree }\end{array}$ & Disagree & Neutral & Agree & $\begin{array}{c}\text { Strongly } \\
\text { Disagree }\end{array}$ & \\
\hline $\begin{array}{c}<1.5 \\
\text { Lakhs }\end{array}$ & 2 & 7 & 4 & 3 & 4 & 20 \\
\hline
\end{tabular}

\begin{tabular}{|c|c|c|c|c|c|c|}
\hline $\begin{array}{c}1.5-5 \\
\text { Lakhs }\end{array}$ & 2 & 6 & 5 & 1 & 0 & 14 \\
\hline $\begin{array}{c}5-10 \\
\text { Lakhs }\end{array}$ & 1 & 4 & 4 & 2 & 1 & 12 \\
\hline $\begin{array}{c}>10 \\
\text { Lakhs }\end{array}$ & 0 & 0 & 2 & 1 & 1 & 4 \\
\hline Total & 5 & 17 & 15 & 7 & 6 & 50 \\
\hline
\end{tabular}

Chi-Square Tests

\begin{tabular}{|c|r|c|c|}
\hline & Value & df & $\begin{array}{c}\text { Asymp. Sig. } \\
\text { (2-sided) }\end{array}$ \\
\hline Pearson Chi-Square & $8.113^{\mathrm{a}}$ & 12 & .776 \\
\hline LikeliHood Ratio & 11.224 & 12 & .510 \\
\hline $\begin{array}{c}\text { Linear-by-Linear } \\
\text { Association }\end{array}$ & .245 & 1 & .651 \\
\hline N of Valid Cases & 50 & & \\
\hline
\end{tabular}

${ }^{\mathrm{a}} 17$ cells $(90.0 \%)$ have expected count less than 5 . The minimum expected count is 0.40 .

\section{Hypothesis:}

- H0: There is no significant difference between the Income of the respondents and cost effective

- H1: There is a significant difference between the Income of the respondents and cost effective

\section{Interpretation:}

- The Table.10 is inferred that the calculated value is 0.776 . The sig value is greater than 0.05 . So H0 is accepted. Hence concluded that there is no significant difference between the income of the respondents and the cost effective.

Table.11. Age of respondents and opinion about Reliance Mutual funds

\begin{tabular}{|c|c|l|l|l|l|}
\hline $\begin{array}{c}\text { Opinion about } \\
\text { Reliance Mutual } \\
\text { funds }\end{array}$ & Age & Mean & S.D & F.V & S.V \\
\hline Timely service & $\begin{array}{c}\text { Below 25 } \\
25-35 \\
35-45 \\
\text { Above 45 }\end{array}$ & 2.9400 & 1.34635 & .182 & .908 \\
\hline Returns & $\begin{array}{c}\text { Below 25 } \\
25-35 \\
35-45\end{array}$ & 3.0000 & 1.14286 & .768 & .518 \\
& Above 45 & & & & \\
\hline Professional \\
management & $\begin{array}{c}\text { Below 25 } \\
25-35 \\
35-45\end{array}$ & 2.7400 & 1.10306 & .694 & .560 \\
\hline Above 45 & & & & \\
\hline Safety of \\
principle & $\begin{array}{c}\text { Below 25 } \\
25-35 \\
35-45\end{array}$ & 2.8636 & 1.08213 & 1.027 & .390 \\
\hline
\end{tabular}

\section{Hypothesis:}

- H0: There is no significant difference between the Age of the respondents and the opinion about Reliance mutual funds. 
- H1: There is a significant difference between the Age of the respondents and the opinion about Reliance mutual funds.

\section{Interpretation:}

- The Table.11 shows the timely service of Reliance mutual funds and Age of the respondents p-value is .908, the timely service is greater than the p-value of 0.05 . There is no statistical significant between timely service and Age of the respondents.

- The Table.11 shows the returns of Reliance mutual funds and Age of the respondents p-value is .518, the returns are greater than the p-value of 0.05 . There is no statistical significant between returns and Age of the respondents.

- The Table.11 shows the professional management of Reliance mutual fund and Age of the respondents p-value is .560 , the professional management is greater than the $\mathrm{p}$ value of 0.05 . There is no statistical significant between professional management and Age of the respondents.

- The Table.11 shows the Safety of principle of Reliance mutual fund and Age of the respondents p-value is .390, the safety of principle is greater than the $p$-value of 0.05 . There is no statistical significant between safety of principle and Age of the respondents.

Table.12. Age of the respondents and the opinion of ICICI mutual funds

\begin{tabular}{|c|c|c|c|c|c|}
\hline $\begin{array}{c}\text { Opinion } \\
\text { about ICICI } \\
\text { Mutual funds }\end{array}$ & Age & Mean & S.D & F.V & S.V \\
\hline Timely service & $\begin{array}{c}\text { Below 25 } \\
25-35 \\
35-45 \\
\text { Above 45 }\end{array}$ & 3.0000 & 1.38505 & .887 & .455 \\
\hline \multirow{2}{*}{ Returns } & $\begin{array}{c}\text { Below 25 } \\
25-35 \\
35-45 \\
\text { Above 45 }\end{array}$ & 2.7600 & 1.17038 & .381 & .767 \\
\hline $\begin{array}{c}\text { Professional } \\
\text { management }\end{array}$ & $\begin{array}{c}\text { Below 25 } \\
25-35 \\
35-45 \\
\text { Above 45 }\end{array}$ & 2.9200 & 1.15776 & .194 & .900 \\
\hline \multirow{2}{*}{$\begin{array}{c}\text { Safety of } \\
\text { principle }\end{array}$} & $\begin{array}{c}\text { Below 25 } \\
25-35\end{array}$ & & & & \\
\hline
\end{tabular}

\section{Hypothesis:}

- H0: There is no significant difference between the Age of the respondents and the opinion about ICICI mutual funds.

- H1: There is a significant difference between the Age of the respondents and the opinion about ICICI mutual funds.

\section{Interpretation:}

- The Table.12 shows the timely service of ICICI mutual funds and age of the respondents p-value is .455 , the timely service is greater than the $\mathrm{p}$-value of 0.05 . There is no statistical significant between timely service and Age of the respondents.
- The Table.12 shows the returns of ICICI mutual funds and Age of the respondents p-value is .767, the returns is greater than the p-value of 0.05 . There is no statistical significant between returns and Age of the respondents.

- The Table.12 shows the professional management of ICICI mutual fund and Age of the respondents p-value is .900, the professional management is greater than the p-value of 0.05 . There is no statistical significant between professional management and Age of the respondents.

- The Table.12 shows the Safety of principle of ICICI mutual fund and Age of the respondents p-value is .249 , the safety of principle is greater than the p-value of 0.05 . There is no statistical significant between safety of principle and Age of the respondents.

Table.13. Age of the respondents and the opinion of Sundaram mutual funds

\begin{tabular}{|c|c|c|c|c|c|}
\hline $\begin{array}{l}\text { Opinion about } \\
\text { Sundaram } \\
\text { Mutual funds }\end{array}$ & Age & Mean & S.D & F.V & S.V \\
\hline Timely service & $\begin{array}{c}\text { Below } 25 \\
25-35 \\
35-45 \\
\text { Above } 45\end{array}$ & 2.9200 & 1.24278 & 1.013 & .396 \\
\hline Returns & $\begin{array}{c}\text { Below } 25 \\
25-35 \\
35-45 \\
\text { Above } 45 \\
\end{array}$ & 2.7200 & 1.21286 & .093 & .963 \\
\hline $\begin{array}{l}\text { Professional } \\
\text { management }\end{array}$ & $\begin{array}{c}\text { Below } 25 \\
25-35 \\
35-45 \\
\text { Above } 45\end{array}$ & 2.9400 & 1.01840 & 0.527 & .666 \\
\hline $\begin{array}{l}\text { Safety of } \\
\text { principle }\end{array}$ & $\begin{array}{c}\text { Below } 25 \\
25-35 \\
35-45 \\
\text { Above } 45\end{array}$ & 2.7400 & 1.12141 & 2.366 & .083 \\
\hline
\end{tabular}

\section{Hypothesis:}

- H0: There is no significant difference between the Age of the respondents and the opinion about Sundaram mutual funds.

- H1: There is a significant difference between the age of the respondents and the opinion about Sundaram mutual funds.

\section{Interpretation:}

- The Table.13 shows the timely service of Sundaram mutual funds and age of the respondents p-value is 0.396 , the timely service is greater than the p-value of 0.05 . There is no statistical significant between timely service and age of the respondents.

- The Table.13 shows the returns of Sundaram mutual funds and age of the respondents p-value is .963 , the returns is greater than the p-value of 0.05 . There is no statistical significant between returns and age of the respondents.

- The Table.13 shows the professional management of Sundaram mutual fund and age of the respondents p-value is .666 , the professional management is greater than the p- 
value of 0.05 . There is no statistical significant between professional management and age of the respondents.

- The Table.13 shows the Safety of principle of Sundaram mutual fund and age of the respondents p-value is .083 , the safety of principle is greater than the p-value of 0.05 . There is no statistical significant between safety of principle and age of the respondents.

Table.14. Age of the respondents and the opinion about HDFC mutual funds

\begin{tabular}{|c|c|c|c|c|c|}
\hline $\begin{array}{c}\text { Opinion about } \\
\text { HDFC Mutual } \\
\text { funds }\end{array}$ & Age & Mean & S.D & F.V & S.V \\
\hline Timely service & $\begin{array}{c}\text { Below } 25 \\
25-35 \\
35-45 \\
\text { Above } 45\end{array}$ & 2.7600 & 1.15281 & .114 & .951 \\
\hline $\begin{array}{l}\text { Rt }=\text { Retq } \\
\text { urns }\end{array}$ & $\begin{array}{c}\text { Below } 25 \\
25-35 \\
35-45 \\
\text { Above } 45\end{array}$ & 2.8800 & 1.25584 & 1.043 & .383 \\
\hline $\begin{array}{l}\text { Professional } \\
\text { management }\end{array}$ & $\begin{array}{c}\text { Below } 25 \\
25-35 \\
35-45 \\
\text { Above } 45\end{array}$ & 2.9000 & 1.21638 & .717 & .547 \\
\hline $\begin{array}{l}\text { Safety of } \\
\text { principle }\end{array}$ & $\begin{array}{c}\text { Below } 25 \\
25-35 \\
35-45 \\
\text { Above } 45\end{array}$ & 3.0400 & 1.27711 & .234 & .872 \\
\hline
\end{tabular}

\section{Hypothesis:}

- H0: There is no significant difference between the age of the respondents and the opinion about HDFC mutual funds.

- H1: There is a significant difference between the age of the respondents and the opinion about HDFC mutual funds.

\section{Interpretation:}

- The Table.14 shows the timely service of HDFC mutual funds and age of the respondents p-value is .951 , the timely service is greater than the p-value of 0.05 . There is no statistical significant between timely service and Age of the respondents.

- The Table.14 shows the returns of HDFC mutual funds and Age of the respondents p-value is .383, the returns is greater than the p-value of 0.05 . There is no statistical significant between returns and Age of the respondents.

- The Table.14 shows the professional management of HDFC mutual fund and age of the respondent's p-value is .547, the professional management is greater than the p-value of 0.05 . There is no statistical significant between professional management and Age of the respondents.

- The Table.14 shows the safety of principle of HDFC mutual fund and age of the respondent's p-value is .872 , the safety of principle is greater than the p-value of 0.05 . There is no statistical significant between safety of principle and Age of the respondents.
Table.15. Age of the respondents and the opinion about Franklin Templeton mutual fund

\begin{tabular}{|c|c|c|c|c|c|}
\hline $\begin{array}{l}\text { Opinion about } \\
\text { Franklin } \\
\text { Templeton } \\
\text { Mutual funds }\end{array}$ & Age & Mean & S.D & F.V & S.V \\
\hline Timely service & $\begin{array}{c}\text { Below } 25 \\
25-35 \\
35-45 \\
\text { Above } 45\end{array}$ & 3.0000 & 1.37024 & .580 & .631 \\
\hline Returns & $\begin{array}{c}\text { Below } 25 \\
25-35 \\
35-45 \\
\text { Above } 45\end{array}$ & 2.8200 & 1.08214 & .531 & .663 \\
\hline $\begin{array}{l}\text { Professional } \\
\text { management }\end{array}$ & $\begin{array}{c}\text { Below } 25 \\
25-35 \\
35-45 \\
\text { Above } 45\end{array}$ & 2.7800 & 1.21706 & 1.565 & .211 \\
\hline $\begin{array}{l}\text { Safety of } \\
\text { principle }\end{array}$ & $\begin{array}{c}\text { Below } 25 \\
25-35 \\
35-45 \\
\text { Above } 45\end{array}$ & 3.2000 & 1.16058 & .415 & .743 \\
\hline
\end{tabular}

\section{Hypothesis:}

- H0: There is no significant difference between the Age of the respondents and the opinion about Franklin Templeton mutual funds.

- H1: There is a significant difference between the Age of the respondents and the opinion about Franklin Templeton mutual funds.

\section{Interpretation:}

- The Table.15 shows the timely service of Franklin Templeton mutual funds and Age of the respondents p-value is .631, the timely service is greater than the p-value of 0.05 . There is no statistical significant between timely service and Age of the respondents.

- The Table.15 shows the returns of Franklin Templeton mutual funds and Age of the respondents p-value is .663, the returns is greater than the p-value of 0.05 . There is no statistical significant between returns and Age of the respondents.

- The Table.15 shows the professional management of Franklin Templeton mutual fund and Age of the respondents p-value is .211, the professional management is greater than the p-value of 0.05 . There is no statistical significant between professional management and Age of the respondents.

- The Table.15 shows the Safety of principle of Franklin Templeton mutual fund and Age of the respondents p-value is .743, the safety of principle is greater than the p-value of 0.05 . There is no statistical significant between safety of principle and Age of the respondents. 


\section{MAJOR FINDINGS}

\subsection{FINDINGS: PERCENTAGE ANALYSIS}

- $(44 \%)$ of the respondents are belongs to the Age group of 35 to 45 years. $34 \%$ of respondents are belongs to the age group of 25 to 35 years. (20\%) of respondents are belongs to the Age group of above 45 years. (2\%) of the respondents are belongs to the Age group below 25 years. Therefore majority of the respondents are between 35 to 45 years.

- $(74 \%)$ respondents are male and $(26 \%)$ respondents are female. Therefore the majority of the respondents are male.

- $(94 \%)$ respondents are married and (6\%) respondents are single. Therefore majority of the respondents are married.

- $(32 \%)$ of the respondents are professionals, (30\%) respondents are in service, $(18 \%)$ of the respondents are in Business, (18\%) respondents are retired, and $(2 \%)$ of the respondent are housewife. Therefore the majority of the respondents are professional.

- $(40 \%)$ of the respondents income is below 1.5 lakh, (28\%) of the respondents income lies between 1.5 to 5 lakhs, (24\%) of the respondents income lies between 5 to 10 lakhs, 4 (8\%) of the respondents income is above 10 lakhs. Therefore majority of the respondents income level is below 1.5 lakhs.

\subsection{CHI-SQUARE}

- From the chi-square income of the respondents are not influenced by the return in investment.

- From the chi-square income of the respondents are not influenced by the lower risk in investment

- From the chi-square income of the respondents are not influenced by the liquidity in investment.

- From the chi-square income of the respondents are not influenced by the convenience in investment.

- From the chi-square income of the respondents are not influenced by the timely service.

- From the chi-square income of the respondents are not influenced by the speedy transaction.

- From the chi-square income of the respondents are not influenced by the good communication.

- From the chi-square income of the respondents are not influenced by the home delivery.

- From the chi-square income of the respondents are not influenced by the cost effective.

\subsection{ANALYSIS OF VARIANCE}

- Age of the respondents are not related with the opinion about Reliance mutual funds.

- Age of the respondents are not related with the opinion about ICICI mutual funds.

- Age of the respondents are not related with the opinion about Sundaram mutual funds.

- Age of the respondents are not related with the opinion about HDFC mutual funds.
- Age of the respondents are not related with the opinion about Franklin Templeton mutual funds.

- Age of the respondents are not related with the opinion about DSPML mutual funds.

- Age of the respondents are not related with the opinion about TATA mutual funds.

\section{SUGGESTIONS}

- In order for a firm to build customer value through managed relationships, the company must identify customers, differentiate them, interact with them, and customize. To build customer value through managed relationships, the company must engage in a four-step process.

- Identifying customers,

- Differentiating them,

- Interacting with them and

- Customizing for them.

- The customer with the age bracket of 26-45 also will provide the best alternative. As this is a segment which actively invests money and also they are looking out for various invest advice and avenues of investing.

- Customers who are either in service and business are better targets as they have a higher tendency to sick with the bank for a longer period of time. Also this is a segment, which will grow faster and have a higher disposable income.

- There is no different between the genders while investing, but normally the locus of decision taking in married women lies with their husband.

\section{CONCLUSION}

It has been established in this study that customer value will always and will only drive the company value and not on their income or age. A trusted agent is one that can be relied upon to make the customers interest paramount, to speak on the customers behalf in all its dealings. Only through a willingness to continually evolve from its core can an organization create true value from other values. Based on the above, it can be concluded that the Indian mutual fund industry is growing at a remarkable pace. However, a large segment of investor is still outside the umbrella of the industry. The reach of the fund houses to different segments of investors is still a key challenge. One possible solution could be increasing financial knowledge and awareness to stimulate investors in mutual fund investment. This will attract investors towards mutual fund investment. The limited distribution network and investor service can be enhanced for wider reach beyond the major cities.

\section{REFERENCES}

[1] A. Bhowal and T. Paul, "Gaps in Customer Solution-A Case Study of Mutual Funds in India”, The SAMS Journal, Vol. 7, No. 2, pp. 33-41, 2013.

[2] A. Bhowal and T. Paul, "Mental Accounting of Retail Investor and Marketing Mix-A Tango", Reflective Journals: Resource for Teachers, Vol. 1, No. 1, pp. 39-48, 2012. 
[3] Confederation of Indian Industry, "Indian Mutual Fund Industry: The Future in a Dynamic Environment", Accessed on 2015 .

[4] M. Dunna, "Mutual funds in India-Issues, Opportunities and Challenges", Asia Pacific Journal of Marketing and Management Review, Vol. 1, No. 2, pp. 240-249, 2012.

[5] Confederation of Indian Industry, "Indian Mutual Fund Industry-Towards Sustaining Inclusive Growth-Evolving Business Models", Available at: https://www.pwc.in/assets/pdfs/financialservice/Towards_2015.pdf, Accessed on 2015.

[6] T. Paul, "A Study on Level of Expectation of Mutual Fund Investors and the Impact of Demographic Profile on Period of Investment", International Journal of Research in Commerce and Management, Vol. 3, No. 7, pp. 136-139, 2012.

[7] T. Paul, "An Assessment of Gap between Expectation an Experience of Mutual Fund Investors", International Journal of Marketing, Financial Services and Management Research, Vol. 1, No. 7, pp. 10-21, 2012.
[8] T. Paul, “A Study on Level of Expectation of Mutual Fund Investors and the Impact of Demographic Profile on Period of Investment", International Journal of Research in Commerce and Management, Vol. 3, No. 7, pp. 136-139, 2012.

[9] B.M. Rama Murthy and S. Reddy, "Recent Trends in the Mutual Fund Industry", SCMS Journal of Indian Management, Vol. 2, No. 3, pp. 27-32, 2005.

[10] G.J. Alexander, J.D. Jones and P.J. Nigro, "Mutual Fund ShareHolders: Characteristics, Investor Knowledge, and Sources of Information", Financial Services Review, Vol. 7, No. 4, pp. 301-316, 1998.

[11] G.J. Alexander, J.D. Jones and P.J. Nigro, "Does Mutual Fund Disclosure at Bank Matter? Evidence from A Survey of Investors", The Quarterly Review of Economics and Finance, Vol. 41, No. 4, pp. 387-403, 2001.

[12] B.M. Barber and T. Odean, "Handbook of the Economics of Finance", Elsevier, 2013.

[13] Confederation of Indian Industry, "Indian Mutual Fund Industry: Unearthing the Growth Potential in Untapped Markets", Available at: www.pwc.com, Accessed on 2015. 